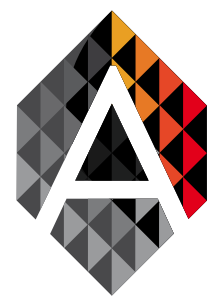

ADCAIJ: Advances in Distributed Computing and Artificial Intelligence Journal Regular Issue, Vol. 8 N. 3 (2019), 35-50

eISSN: $2255-2863$

DOI: http://dx.doi.org/10.14201/ADCAIJ2019833550

\title{
Ranking Factors Affecting Organizational Readiness to Implement Enterprise Resource Planning Systems Using Fuzzy-Dimensional Network Analysis
}

\author{
Farzaneh Zafary Asheghdoost \\ Islamic Azad University E-Campus, Iran, Tehran \\ f.zafary@gmail.com
}

$\begin{array}{ll}\text { KEYWORD } & \text { ABSTRACT } \\ \begin{array}{ll}\text { Enterprise } & \text { Whenever an organization decides to implement an ERP, it must assess its readiness to } \\ \text { Resource } & \text { implement these complex systems. Therefore, the present study aims at considering the } \\ \text { Planning (ERP); } & \text { pre-implementation phase of ERP and the factors affecting the readiness of the organi- } \\ \text { SWOT Analysis; } & \text { zation for successful implementation of these systems. In this research, the SWOT matrix } \\ \text { Network Analysis; } & \text { was used to classify the identified factors. Moreover, fuzzy-dimensional network analysis } \\ \text { Fuzzy Dematel } & \text { was used to evaluate decision options due to the weakness of SWOT technique. Since the } \\ & \text { factors involved in SWOT analysis are not only disjointed, but sometimes there are rela- } \\ & \text { tionships among some of its factors. Therefore, internal and external factors of the orga- } \\ \text { nization are evaluated and prioritized in the research. In addition, finding the strategic } \\ \text { position of the organization and identifying the appropriate strategies and prioritizing } \\ \text { them to improve the organization's readiness for ERP implementation were other tasks } \\ \text { in this research. After analyzing the data, } 25 \text { organizational factors are prioritized. The } \\ \text { numerical results indicated that the organization is in the offensive position therefore, } \\ \text { four strategies are designed and prioritized according to its position. }\end{array} \\ \end{array}$

\section{Introduction}

In order to meet the organizational needs to process management, Enterprise Resource Planning (ERP) systems provide the ability to manage and plan by integrating information and services for different processes. Therefore, ERP systems are essential for integrating and enhancing the productivity of organizations. ERP consists of three stages before and after implementation, and undoubtedly the pre-implementation stage plays an important role in the success and failure of the organization in implementing these systems.

It should be noted that implementation of ERP will not always be beneficial however, for some organizations it will be better not to implement it. Hence, implementation of such complex and costly systems should be accompanied by researching and planning, while identifying the goals of the organization from the implementation of this system, considering internal and external effective factors for better decision making.

Farzaneh Zafary Asheghdoost

Ranking Factors Affecting Organizational Readiness to Implement Enterprise Resource Planning Systems Using Fuzzy-Dimensional Network Analysis
ADCAIJ: Advances in Distributed Computing and Artificial Intelligence Journal Regular Issue, Vol. 8 N. 3 (2019), 35-50 elSSN: 2255-2863 - http://adcaij.usal.es Ediciones Universidad de Salamanca - CC BY NC DC 
One of the early steps for deploying organizational resource planning systems is a feasibility study and evaluation of organizational readiness for acceptance and proper utilization of these systems (Musikhani et al., 2014). In this applied research, a descriptive-survey method is chosen as a methodology to prioritize the factors that influence the success of an organization in implementing ERP and identify organizational strategies. Therefore, the researcher needs to identify the controllable and uncontrollable factors affecting the success of ERP systems by analyzing the internal and external environment of the organization and guide the organization in making better and better decisions.

Nowadays, not only manufacturing companies, but also service companies including universities are seeking to increase customer satisfaction, speed up workflow with minimal error, increase the ability to manage and plan by integrating systems and organizational information. Because of the importance of the way educational institutions operate in Iran, a chosen organization is a university, a service-learning institution, with a large number of clients who need to work in a coordinated manner. In order to evaluate the readiness of the organization under study, we used strategic management approach and ranking of indicators. Moreover, in order to accomplish the goals of the present study, the researcher have gathered the opinions of experts in the field of ERP and familiar with the university environment while utilizing internal and external studies. After considering the SWOT matrix using a hybrid approach with multi-criteria decision making tools, the researcher examine and prioritize the relationships among organizational factors.

Research results in 2013 showed that $54 \%$ of reported ERP projects were out of cost and $72 \%$ out of time and $66 \%$ of organizations implementing ERP software have less than $50 \%$ of the anticipated measurable benefits (Dodaya \& et al., 2014). As can be seen from the results, the failure rate is high in the implementation of ERP systems, and one of the important reasons could be the failure of a strong project team to measure the readiness of the organization. In the preparation phase, the researcher may realize that the organization does not need to implement these integrated programs, because it does not only work well but also causes losses and small organizations sometimes face this challenge.

The readiness of the organization can be defined as: the degree of readiness of the organization, so when the project is completed, a glance can be made that the project is going smoothly. The readiness of an organization can be measured as a percentage in the [0 - 100] range (Ahmadi et al., 2015a). Evaluating the readiness of an organization to implement ERP systems is done in a variety of ways, and it is essential that the project team searches for a way to achieve even more accurate results. It is also important that an organization knows its internal and external environment, decide whether to implement integrated ERP systems and adopt appropriate strategies to improve the status of the organization. One of the methods that can help the organization in this regard is the SWOT analysis method. On the other hand, other methods such as the Network Analysis Process (ANP) can be used to determine the importance of each of the identified organizational factors and provide a solution for evaluating decision options. Therefore, the organization can make the best decisions by recognizing the internal and external factors that influence the success of ERP systems implementation in order to reduce the failures during ERP implementation.. In the higher education system, environmental changes, especially new developments in information technology, have led to strategic changes in universities. It is believed that formulating a strategic plan tailored to the specificity of each university has in most cases been associated with effectiveness outcomes (Nazemi et al., 2010). Thus, prior to the establishment of ERP systems, identifying the factors affecting the success of the organization with regard to the goals is essential. It is also necessary for organizations to go through the ERP implementation process precisely to minimize the likelihood of failure.. In this study, identifying the internal and external factors and how they influence each other, the Birjand University strategies in the field of implementation of integrated systems are examined. Then all the factors obtained and the strategies formulated with the strategic position of the organization are prioritized. The causality among the various factors should include a comprehensive model of readiness assessment because preparation activities will affect one another (Kayak and Lee, 2008). It should be noted that in addition to educational institutions, other organizations can also benefit from this research and use the strengths, weaknesses, opportunities, and threats of the organization and with regard to the goals they pursue to avoid potential failures.

Farzaneh Zafary Asheghdoost

Ranking Factors Affecting Organizational Readiness to

Implement Enterprise Resource Planning Systems Using

Fuzzy-Dimensional Network Analysis
ADCAIJ: Advances in Distributed Computing and Artificial Intelligence Journal Regular Issue, Vol. 8 N. 3 (2019), 35-50 eISSN: 2255-2863 - http://adcaij.usal.es Ediciones Universidad de Salamanca - CC BY NC DC 


\subsection{Research Objective}

- Many research studies have been carried out in manufacturing companies and the implementation or evaluation phase after ERP implementation has been considered. But in the present study the pre-implementation phase of ERP systems is discussed, which is an important issue.

- In this study, a university is selected, where is an educational service provider environment. As an organization that faces a large number of clients every day, the university needs an integrated and up-to-date system to be able to respond quickly and easily to clients as well as to satisfy them and their staff. Thus, the researcher chose Birjand University for a case study. However, no such research has been done at the university so far.

- In this study, the researcher has tried to identify the factors affecting the readiness of an organization in details for successful implementation of ERP by using SWOT analysis to categorize the internal and external Moreover, by combining fuzzy dimensional methods and network analysis, while identifying possible dependencies among the factors, the researcher prioritizes the relevant factors and strategies. However, the combination of these three approaches was not found in reviewing internal and external articles in the field of measuring organizational readiness and developing appropriate strategies to improve readiness for ERP implementation.

The research questions are as follows:

1) What are the strengths and weaknesses of Birjand University in implementing ERP systems?

2) What are the opportunities and threats for Birjand University in implementing ERP systems?

3) How important are each factor's strengths, weaknesses, opportunities, and threats to the organization?

4) What is the strategic position of the organization to implement ERP systems?

5) What are the strategies to improve the organization's readiness for successful ERP implementation and how should they be implemented?

\section{Research methodology}

This study is an applied research and in terms of method, it is a descriptive-survey research. The purpose of this study was to evaluate the organization's readiness to implement ERP systems at Birjand University. There are various factors in an organization's readiness to implement ERP. These factors have been mentioned in numerous studies and studies and are closely related to each other. Therefore, to identify the existing relationships by fuzzy dimensional technique, to determine the priority of the identified factors by the network analysis technique and to select the strategy from the SWOT technique Based on what has been said, a general algorithm can be presented in fig1.

Farzaneh Zafary Asheghdoost

Ranking Factors Affecting Organizational Readiness to Implement Enterprise Resource Planning Systems Using Fuzzy-Dimensional Network Analysis
ADCAIJ: Advances in Distributed Computing and Artificial Intelligence Journal Regular Issue, Vol. 8 N. 3 (2019), 35-50 eISSN: 2255-2863 - http://adcaij.usal.es Ediciones Universidad de Salamanca - CC BY NC DC 


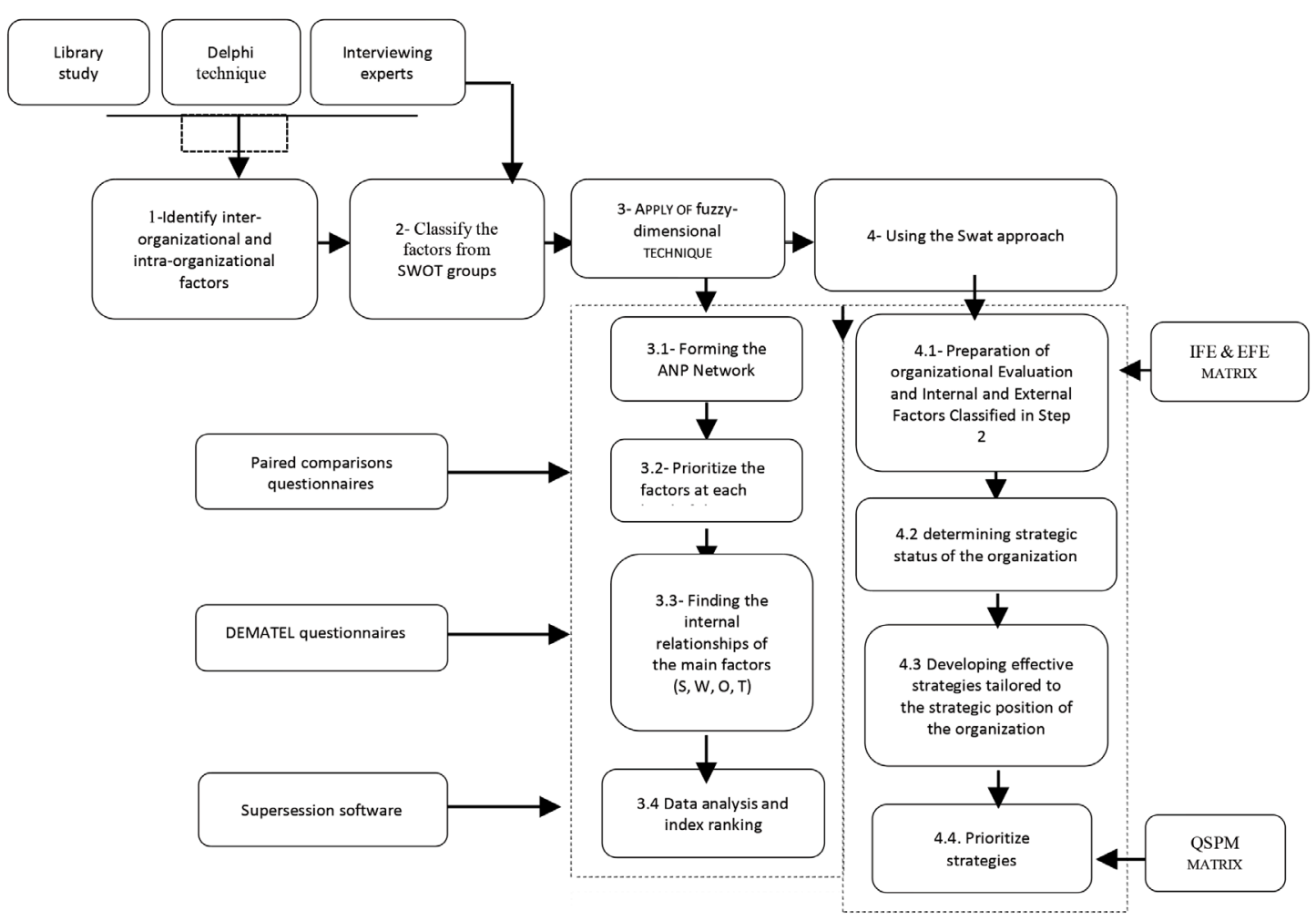

Figure 1: Research methodology algorithm.

The study was conducted at Birjand University. Birjand University currently has 11 faculties as the educational and educational hub of the East of the country and the largest and oldest institute of higher education in South Khorasan province with 11225 students in 318 field codes in undergraduate, postgraduate and doctoral level, and 332 permanent faculty members and 385 students as an employee. Therefore, the study population is comprised of experts and senior experts in the field under study. At each stage of the study, a group of experts is assigned based on the technique used. Multivariate decision-making techniques such as fuzzy and dimensional network analysis and SWOT approach have been used to achieve this research. As a result, 10 experts from Birjand University were surveyed as examples. The data collection methods in this study are divided into two categories: library and field. Library methods were used to collect information on the subject literature and research background and field method was used to collect information to answer research questions. Questionnaire was used to collect the required data. The main questionnaire used is the expert questionnaire. The expert questionnaire in the present study includes Delphi questionnaires, network analysis and fuzzy dimensional questionnaire with relationships among the main indicators. It is essential that the practitioner establishes the relative reliability of the instrument, so the validity and reliability of the instruments used in the research should be assessed. In this study, to determine the weight of model variables, the group network analysis process based on the results of the paired AHP questionnaire based on the Saaty's 9 scales was used, which is a scientifically accepted method by many experts. This questionnaire has some kind of logical and content validity in determining the relative weights of variables. Because all factors in the model are considered and matched in the questionnaire, all the probabilities associated with not considering a variable will be eliminated. On the other hand, as the questionnaire scales and measures all criteria in a two-way manner, the maximum possible questions are asked in a descriptive way, and because all the criteria are taken into account in the measurement, the designer is not able to direct the design of the questions. There is no need to measure reliability. On the other hand, since the questionnaire is based on hierarchical analysis and Saaty scale of analysis, therefore, an index called incompatibility index is used to evaluate the questionnaire. These indicators suggest that if the inconsistency of the 
pairwise comparisons is greater than 0.1 , it is better to revise the comparisons. In this study, Delphi techniques, fuzzy dimensional, network analysis process and SWOT approach were used to determine the weight and prioritize the criteria and formulate the strategy. For this purpose, the paired matrix was used to determine the weight of the criteria and then we applied several techniques over several stages.

\subsection{Delphi technique}

Delphi is a cheap, multifunctional, objective, non-threatening, easy to identify and understand method, and provides empirical evidence through extensive use of opinions and strong consensus of views, especially in cases of inadequacy and deficiency. High flexibility of approach, application in different systems, application of different communication approaches and the possibility of being used in a wide geographical level, no need for interviewer training, anonymity, open discussion, identification and underlying understanding of Delphi are other advantages. This technique avoids wasting time and energy on irrelevant or biased decisions because Delphi predictions are made in an analytical and systematic way (Helm, 2005).

There are no explicit rules on how to select and number of experts and their numbers depend on the factors of sample homogeneity or heterogeneity, Delphi goal or problem area, decision quality, the ability of the research team to study, internal and external validity and time of data collection. Moreover, the resources available, the scope of the problem, and the acceptance of the answer are typically less than 50 participants, often 15 to 20 (Alenda, 2006). Delphi measurement using a 7-point Likert scale questionnaire and indices having mean the following 4 were eliminated in each round until the final consensus was reached. The Likert scale is one of the most common attitudinal measures and includes a set of metrics or expressions that respondents indicate their agreement with each of the terms in a grading range that is typically one to five (or seven) degrees (Sarmad et al., 1997). The research method of this research is as follows:

1. Identify inter-organizational and intra-organizational factors affecting an organization's readiness to successfully implement ERP by using library study, interviewing experts (familiar with ERP, strategic issues and campus) and distributing Delphi questionnaires among them.

2. Classify the factors from the previous step into groups of strengths, weaknesses, opportunities and threats according to an expert ERP expert and familiar with the strategic issues of Birjand University.

3. Application of fuzzy-dimensional network analysis technique

\subsection{Forming the ANP Network}

3.2. Prioritize the factors at each level of the ANP network with paired comparisons and use expert opinions while distributing expert questionnaires among them.

3.3. Finding the internal relationships of the main factors (strengths, weaknesses, opportunities and threats) using expert opinions while distributing the expert questionnaire among them and applying the fuzzy DEMATEL method.

3.4. Data analysis with supersession software and index ranking.

4. Using the Swat approach

4.1. Preparation of Internal Factor Evaluation (IFE) and External Factor (EFE) Matrix for Factors Classified in Step 2

4.2. Drawing the strategic position diagram of the organization and determining its strategic status according to the results of the previous step.

4.3. Developing effective strategies tailored to the strategic position of the organization.

4.4. Prioritize strategies by providing a quantitative matrix of strategic planning (QSPM).

Farzaneh Zafary Asheghdoost

Ranking Factors Affecting Organizational Readiness to Implement Enterprise Resource Planning Systems Using Fuzzy-Dimensional Network Analysis
ADCAIJ: Advances in Distributed Computing and Artificial Intelligence Journal Regular Issue, Vol. 8 N. 3 (2019), 35-50 eISSN: 2255-2863 - http://adcaij.usal.es Ediciones Universidad de Salamanca - CC BY NC DC 


\section{Discussion and findings}

The purpose of this study was to identify and prioritize the effective factors in the implementation of ERP at Birjand University. In this research, the key factors behind the success of ERP that was most frequently found in research sources were identified. Moreover, the framework of the research theory was confirmed by interviewing process experts and process experts. This framework is listed in Table 1.

Table 1: Factors in preparation for the implementation of the Enterprise Resource Planning

\begin{tabular}{|c|c|c|}
\hline Sub agents & Sources & Main factors \\
\hline $\begin{array}{l}\text { Each team, determine the goals and mission of a clear process } \\
\text { on the basis of the mission of the preparatory process and aims } \\
\text { to improve the process }\end{array}$ & Sadeghi et al, (2011) & \multirow{5}{*}{$\begin{array}{c}\text { Team and } \\
\text { teamwork D1 }\end{array}$} \\
\hline $\begin{array}{l}\text { create multi-functional process of the members who have } \\
\text { enough knowledge. }\end{array}$ & \multirow{2}{*}{ Bandara et al, (2009) } & \\
\hline Formation of a knowledge-based team & & \\
\hline $\begin{array}{l}\text { Establish a system of identification and rewards based on } \\
\text { individual participation }\end{array}$ & $\begin{array}{l}\text { Bandara et al, (2009) } \\
\text { Telleria et al, }(2002)\end{array}$ & \\
\hline $\begin{array}{l}\text { Design of measuring instruments for measuring team } \\
\text { performance }\end{array}$ & $\begin{array}{l}\text { Sadeghi et al, }(2011) \\
\text { Bandara et al, }(2009) \\
\text { Telleria et al, }(2002)\end{array}$ & \\
\hline $\begin{array}{l}\text { Exchange strategic goals, prospects and key business goals } \\
\text { throughout the organization }\end{array}$ & $\begin{array}{l}\text { Sadeghi et al, (2011) } \\
\text { Haji Sadeghi et al (2009), } \\
\text { Juran and Blanton (2000) } \\
\text { McSweeney, (2009) }\end{array}$ & \multirow{4}{*}{$\begin{array}{l}\text { Communication } \\
\text { and awareness D2 }\end{array}$} \\
\hline $\begin{array}{l}\text { Support senior management on the importance and role of } \\
\text { ERP and its benefits }\end{array}$ & \multirow{2}{*}{$\begin{array}{l}\text { Sadeghi, et al (2011) } \\
\text { Baidoun, (2004) } \\
\text { Telleria et al, (2002) }\end{array}$} & \\
\hline $\begin{array}{l}\text { Staff awareness of the significance of processes and roles and } \\
\text { responsibilities }\end{array}$ & & \\
\hline $\begin{array}{l}\text { Channel created various communication horizontally and } \\
\text { vertically, up and down }\end{array}$ & $\begin{array}{l}\text { Bandara et al, (2009) } \\
\text { Rezaei et al, (2009) }\end{array}$ & \\
\hline Exchange information and review customer information & Telleria et al, (2002) & \\
\hline $\begin{array}{l}\text { Employees at all levels have the opportunity and opportunity } \\
\text { to increase participation }\end{array}$ & Juran and Blanton, (2000) & \multirow{4}{*}{$\begin{array}{l}\text { Empowering } \\
\text { employees D3 }\end{array}$} \\
\hline The ability of employees to take appropriate actions. & \multirow{2}{*}{ Bandara et al, (2009) } & \\
\hline Align employee goals with high company goals & & \\
\hline $\begin{array}{l}\text { Committing employees to the goals of the organization and } \\
\text { achieving them }\end{array}$ & $\begin{array}{l}\text { Jura and Blanton, }(2000) \\
\text { Rezaei et al, (2009) }\end{array}$ & \\
\hline
\end{tabular}

Farzaneh Zafary Asheghdoost

Ranking Factors Affecting Organizational Readiness to Implement Enterprise Resource Planning Systems Using Fuzzy-Dimensional Network Analysis
ADCAIJ: Advances in Distributed Computing and Artificial Intelligence Journal Regular Issue, Vol. 8 N. 3 (2019), 35-50 eISSN: 2255-2863 - http://adcaij.usal.es Ediciones Universidad de Salamanca - CC BY NC DC 


\begin{tabular}{|c|c|c|}
\hline Sub agents & Sources & Main factors \\
\hline $\begin{array}{l}\text { Determine the input and output of key processes such as data, } \\
\text { information and equipment and processes other and... }\end{array}$ & $\begin{array}{l}\text { Juran and Blanton, (2000) } \\
\text { Rezaei et al, (2009) }\end{array}$ & \multirow{4}{*}{ Process map D4 } \\
\hline $\begin{array}{l}\text { Identify suppliers and customers as key processes to get } \\
\text { suppliers and or procurement of materials, information and... }\end{array}$ & \multirow{2}{*}{$\begin{array}{l}\text { McSweeney, (2009) } \\
\text { Rezaei et al, (2009) } \\
\text { Juran and Blanton, (2000) }\end{array}$} & \\
\hline (Specify process levels (process, sub process and activity & & \\
\hline $\begin{array}{l}\text { The design process maps and flow charts inputs and outputs of } \\
\text { each process is key }\end{array}$ & $\begin{array}{l}\text { Juran and Blanton, (2000) } \\
\text { Rezaei et al, (2009) }\end{array}$ & \\
\hline Skills training to identify and solve problems & $\begin{array}{l}\text { Bandara, et al, (2009) } \\
\text { Telleria et al, (2002) }\end{array}$ & \multirow{5}{*}{ Education D5 } \\
\hline $\begin{array}{l}\text { Professional quality control and improvement to the team } \\
\text { leader }\end{array}$ & $\begin{array}{l}\text { Haji Sadeghi et al, (2009) } \\
\text { Ravesteyn (2010) }\end{array}$ & \\
\hline $\begin{array}{l}\text { Create a system in place to identify training needs in three } \\
\text { levels: system, team and individual }\end{array}$ & \multirow{2}{*}{$\begin{array}{l}\text { Bandara, et al, (2009) } \\
\text { Baidoun, (2004) }\end{array}$} & \\
\hline Teamwork skills training among staff & & \\
\hline $\begin{array}{l}\text { Skills training response (communication skills, effective } \\
\text { meetings and leadership training) }\end{array}$ & $\begin{array}{l}\text { Bandara, et al, (2009) } \\
\text { Baidoun, (2004) }\end{array}$ & \\
\hline $\begin{array}{l}\text { Existence of change management skills in the organization to } \\
\text { facilitate change }\end{array}$ & \multirow{2}{*}{$\begin{array}{l}\text { Haji Sadeghi et al (2009) } \\
\text { Ravesteyn (2010) } \\
\text { Juran and Blanton, (2009) }\end{array}$} & \multirow{4}{*}{$\begin{array}{c}\text { change } \\
\text { management D6 }\end{array}$} \\
\hline $\begin{array}{l}\text { Ability to overcome resistance to change between owner and } \\
\text { process team }\end{array}$ & & \\
\hline Preparing for Change (Model for Chang) & $\begin{array}{l}\text { Haji Sadeghi et al, (2009) } \\
\text { Juran and Blanton, (2000) }\end{array}$ & \\
\hline $\begin{array}{l}\text { Skills extensive of project management to enabling process } \\
\text { management team to manage the timing, cost, coordination } \\
\text { and implementation of the program of work in the } \\
\text { organization. } \\
\text { (Skill of changing management in organization) }\end{array}$ & $\begin{array}{l}\text { Haji Sadeghi et al (2009) } \\
\text { Ravesteyn (2010) } \\
\text { Juran and Blanton, (2000) } \\
\text { Bandara, et al, (2009) }\end{array}$ & \\
\hline IT capability & $\begin{array}{l}\text { Bandara, et al, (2009) } \\
\text { Kalhori and Haji Heidari, } \\
(2012)\end{array}$ & \multirow{4}{*}{$\begin{array}{l}\text { Information } \\
\text { Technology D7 }\end{array}$} \\
\hline Having under construction IT & $\begin{array}{l}\text { Bandara, et al, (2009) } \\
\text { Kalhori and Haji Heidari, } \\
(2012)\end{array}$ & \\
\hline Create a database within the organization & $\begin{array}{l}\text { Haji Sadeghi et al (2009) } \\
\text { McSweeney, (2009) }\end{array}$ & \\
\hline $\begin{array}{l}\text { Establish a network of related information and finding the } \\
\text { right partners }\end{array}$ & $\begin{array}{l}\text { Haji Sadeghi et al (2009) } \\
\text { McSweeney, (2009) }\end{array}$ & \\
\hline
\end{tabular}

In order to screen and localize the identified factors, experts were asked to respond to the significance level of each identified factor based on the Likert five-range spectrum. Then, the questionnaire was collected and the geometric mean of the given scores was calculated and the factors that were higher than the average significance level (3) were selected as important factors and other factors were eliminated. Therefore, seven key factors and

Farzaneh Zafary Asheghdoost

Ranking Factors Affecting Organizational Readiness to Implement Enterprise Resource Planning Systems Using Fuzzy-Dimensional Network Analysis
ADCAIJ: Advances in Distributed Computing and Artificial Intelligence Journal Regular Issue, Vol. 8 N. 3 (2019), 35-50 elSSN: 2255-2863 - http://adcaij.usal.es Ediciones Universidad de Salamanca - CC BY NC DC 
25 sub-factors were selected as important and effective factors in the implementation of enterprise resource planning systems. To determine the relationships and severity of factors affecting each other by DEMATEL method, paired comparisons questionnaire was designed and experts based on the linguistic options in Table (1) determined the extent of influence of each factor on the other factor. Subsequently, the comments were converted to fuzzy numbers and pooled using arithmetic mean and the fuzzy decision matrix was compiled as in Table 2.

Table 2: Fuzzy direct relation matrix between the main factors

\begin{tabular}{|c|c|c|c|c|c|c|c|c|c|c|c|c|c|c|}
\hline & \multicolumn{4}{|c|}{ D1 } & \multicolumn{4}{c|}{ D2 } & $\ldots$ & \multicolumn{3}{c|}{ D6 } & \multicolumn{3}{c|}{ D7 } \\
\cline { 2 - 16 } & L. & M & U & L. & M & U & & L. & M & U & L. & M & U \\
\hline D1 & 0 & 0 & 0 & $0 / 75$ & 1 & 1 & $\ldots$ & $0 / 438$ & $0 / 65$ & $0 / 9$ & $0 / 3$ & $0 / 55$ & $0 / 8$ \\
\hline D2 & 0 & $0 / 25$ & $0 / 5$ & 0 & 0 & 0 & $\ldots$ & $0 / 25$ & $0 / 5$ & $0 / 75$ & $0 / 4$ & $0 / 65$ & $0 / 85$ \\
\hline D3 & $0 / 4$ & $0 / 65$ & $0 / 85$ & $0 / 6$ & $0 / 85$ & $0 / 95$ & $\ldots$ & $0 / 5$ & $0 / 75$ & 1 & $0 / 5$ & $0 / 75$ & 1 \\
\hline D4 & $0 / 4$ & $0 / 65$ & $0 / 85$ & $0 / 3$ & $0 / 55$ & $0 / 8$ & $\ldots$ & $0 / 5$ & $0 / 75$ & 1 & $0 / 35$ & $0 / 6$ & $0 / 8$ \\
\hline D5 & $0 / 55$ & $0 / 8$ & 1 & $0 / 6$ & $0 / 85$ & $0 / 95$ & $\ldots$ & $0 / 313$ & $0 / 65$ & $0 / 85$ & $0 / 55$ & $0 / 8$ & $0 / 95$ \\
\hline D6 & $0 / 25$ & $0 / 5$ & $0 / 75$ & $0 / 25$ & $0 / 5$ & $0 / 75$ & $\ldots$ & 0 & 0 & 0 & $0 / 35$ & $0 / 6$ & $0 / 85$ \\
\hline D7 & $0 / 4$ & $0 / 65$ & $0 / 85$ & $0 / 6$ & $0 / 85$ & 1 & $\ldots$ & $0 / 313$ & $0 / 65$ & $0 / 85$ & 0 & 0 & 0 \\
\hline
\end{tabular}

Note: Due to the huge matrix $7 * 7$ and the small size matrix displays all the tables are in compressed form.

Subsequently, the maximum of the sum of rows and columns was calculated and then the matrix numbers were divided into larger values. The fuzzy normalized matrix was then calculated for the factors. This matrix is listed in Table 3.

Table 3: The fuzzy normalization matrix between the main factors

\begin{tabular}{|c|c|c|c|c|c|c|c|c|c|c|c|c|c|}
\hline & \multicolumn{4}{|c|}{ D1 } & \multicolumn{4}{c|}{ D2 } & $\ldots$ & \multicolumn{3}{c|}{ D6 } & \multicolumn{3}{c|}{ D7 } \\
\cline { 2 - 15 } & L. & M & U & L. & M & U & & L. & M & U & L. & M & U \\
\hline D1 & 0 & 0 & 0 & $0 / 24$ & $0 / 22$ & $0 / 18$ & $\ldots$ & $0 / 14$ & $0 / 14$ & $0 / 16$ & $0 / 1$ & $0 / 12$ & $0 / 14$ \\
\hline D2 & 0 & $0 / 05$ & $0 / 09$ & 0 & 0 & 0 & $\ldots$ & 08 & $0 / 11$ & $0 / 14$ & $0 / 13$ & $0 / 14$ & $0 / 15$ \\
\hline D3 & $0 / 13$ & $0 / 14$ & $0 / 15$ & $0 / 19$ & $0 / 18$ & $0 / 17$ & $\ldots$ & $0 / 16$ & $0 / 16$ & $0 / 18$ & $0 / 16$ & $0 / 16$ & $0 / 18$ \\
\hline D4 & $0 / 13$ & $0 / 14$ & $0 / 15$ & $0 / 1$ & $0 / 12$ & $0 / 14$ & $\ldots$ & $0 / 16$ & $0 / 16$ & $0 / 18$ & $0 / 11$ & $0 / 13$ & $0 / 14$ \\
\hline D5 & $0 / 17$ & $0 / 17$ & $0 / 18$ & $0 / 19$ & $0 / 18$ & $0 / 17$ & $\ldots$ & $0 / 1$ & $0 / 14$ & $0 / 15$ & $0 / 17$ & $0 / 17$ & $0 / 17$ \\
\hline D6 & $0 / 08$ & $0 / 11$ & $0 / 14$ & $0 / 08$ & $0 / 11$ & $0 / 14$ & $\ldots$ & 0 & 0 & 0 & $0 / 11$ & $0 / 13$ & $0 / 15$ \\
\hline D7 & $0 / 13$ & $0 / 14$ & $0 / 15$ & $0 / 19$ & $0 / 18$ & $0 / 18$ & $\ldots$ & $0 / 1$ & $0 / 14$ & $0 / 15$ & 0 & 0 & 0 \\
\hline
\end{tabular}

Note: Due to the huge matrix $7 * 7$ and the small size matrix displays all the tables are in compressed form.

The matrix of fuzzy total $\mathrm{T}$ relations (relative intensity of direct and indirect relationships) was calculated below. The general relations matrix is a matrix that shows the intensity of all possible direct and indirect relationships derived from expert responses. Fuzzy numbers are fuzzy centered [g1]. The matrix of fuzzy generalized relationships between the principal and sub-factors is given in Tables 4 and 5 .

Farzaneh Zafary Asheghdoost

Ranking Factors Affecting Organizational Readiness to Implement Enterprise Resource Planning Systems Using

Fuzzy-Dimensional Network Analysis

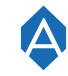

ADCAIJ: Advances in Distributed Computing and Artificial Intelligence Journal Regular Issue, Vol. 8 N. 3 (2019), 35-50 eISSN: 2255-2863 - http://adcaij.usal.es Ediciones Universidad de Salamanca - CC BY NC DC 
Table 4: The matrix of general fuzzy relations between the main factors

\begin{tabular}{|c|l|c|c|c|c|c|c|c|}
\hline \multicolumn{2}{|c|}{ main factors } & D1 & D2 & D3 & D4 & D5 & D6 & D7 \\
\hline D1 & Team and teamwork & $0 / 953$ & $1 / 336$ & $1 / 338$ & $1 / 032$ & $1 / 173$ & $1 / 191$ & $1 / 178$ \\
\hline D2 & Communication and awareness & $0 / 872$ & $0 / 985$ & $1 / 152$ & $0 / 911$ & $1 / 012$ & $1 / 009$ & $1 / 04$ \\
\hline D3 & Empowering employees & $1 / 077$ & $1 / 31$ & $1 / 171$ & $1 / 034$ & $1 / 172$ & $1 / 206$ & $1 / 213$ \\
\hline D4 & Process map & $1 / 05$ & $1 / 222$ & $1 / 252$ & $0 / 906$ & $1 / 15$ & $1 / 173$ & $1 / 147$ \\
\hline D5 & Education & $1 / 166$ & $1 / 392$ & $1 / 421$ & $1 / 107$ & $1 / 117$ & $1 / 246$ & $1 / 287$ \\
\hline D6 & change management & $0 / 947$ & $1 / 114$ & $1 / 146$ & $0 / 938$ & $1 / 054$ & $0 / 942$ & $1 / 061$ \\
\hline D7 & Information Technology & $1 / 062$ & $1 / 293$ & $1 / 283$ & $1 / 037$ & $1 / 155$ & $1 / 161$ & $1 / 051$ \\
\hline
\end{tabular}

Table 5: Matrix relationships of fuzzy removing the following factors (TC)

\begin{tabular}{|c|c|c|c|c|c|c|c|c|c|}
\hline & & \multicolumn{4}{|c|}{ D1 } & \multicolumn{4}{|c|}{ D7 } \\
\hline & & $\mathrm{C} 11$ & $\mathrm{C} 12$ & $\mathrm{C} 13$ & $\mathrm{C} 14$ & C71 & C72 & C73 & C74 \\
\hline \multirow{4}{*}{ D1 } & $\mathrm{C} 11$ & $0 / 24$ & $0 / 28$ & $0 / 26$ & $0 / 26$ & $0 / 24$ & $0 / 24$ & $0 / 26$ & $0 / 25$ \\
\hline & $\mathrm{C} 12$ & $0 / 27$ & $0 / 24$ & $0 / 24$ & $0 / 25$ & $0 / 24$ & $0 / 24$ & $0 / 25$ & $0 / 25$ \\
\hline & $\mathrm{C} 13$ & $0 / 25$ & $0 / 26$ & $0 / 2$ & $0 / 24$ & $0 / 21$ & $0 / 22$ & $0 / 22$ & $0 / 22$ \\
\hline & C14 & $0 / 24$ & $0 / 24$ & $0 / 23$ & $0 / 2$ & $0 / 21$ & $0 / 21$ & $0 / 22$ & $0 / 23$ \\
\hline \multirow{4}{*}{ D2 } & D71 & $0 / 27$ & $0 / 27$ & $0 / 25$ & $0 / 25$ & $0 / 2$ & $0 / 23$ & $0 / 24$ & $0 / 24$ \\
\hline & D72 & $0 / 3$ & $0 / 3$ & $0 / 27$ & $0 / 28$ & $0 / 26$ & $0 / 23$ & $0 / 27$ & $0 / 28$ \\
\hline & D73 & $0 / 3$ & $0 / 3$ & $0 / 27$ & $0 / 28$ & $0 / 26$ & $0 / 27$ & $0 / 23$ & $0 / 28$ \\
\hline & D74 & $0 / 29$ & $0 / 3$ & $0 / 28$ & $0 / 28$ & $0 / 26$ & $0 / 27$ & $0 / 28$ & $0 / 24$ \\
\hline
\end{tabular}

Note: With respect to a matrix of $25 * 25$ and the low-page matrix, all the tables can be displayed compact.

According to Table 4, the "team and teamwork" factor affects 1.336 on the "communication and awareness" factor, while it affects 0.872 of this variable. Therefore, the intensity of group and teamwork is more influential on communication and awareness, and recognizing this impact can play a significant role in decision making. The $\mathrm{T}$ matrix determines the severity of the influence of factors. Therefore, to determine the overall effect of an agent, the sum of its effectiveness (D) and its impressionability (R) are calculated. Finally, the extent of its interaction with other factors and the net effectiveness and impressionability are determined. These calculations are listed in Table 6. According to the results of Table (6), the factors of "teamwork and team", "process map" and "training" with positive values are the most influential factors that lead to improvement of the system. The factors of "communication and awareness", "change management", "information technology" and "staff empowerment" are negatively influenced and are more influenced by appropriate action. The factors of "teamwork and workgroup", "process map" and "training" improve the factors of "communication and awareness", "change management", and "staff empowerment".

Farzaneh Zafary Asheghdoost

Ranking Factors Affecting Organizational Readiness to Implement Enterprise Resource Planning Systems Using Fuzzy-Dimensional Network Analysis

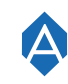

ADCAIJ: Advances in Distributed Computing and Artificial Intelligence Journal Regular Issue, Vol. 8 N. 3 (2019), 35-50 elSSN: 2255-2863 - http://adcaij.usal.es Ediciones Universidad de Salamanca - CC BY NC DC 
Table 6: effectiveness and impact of factors and sub-factors

\begin{tabular}{|c|c|c|c|c|}
\hline R-D & $\mathbf{R}+\mathbf{D}$ & D & $\mathbf{R}$ & Agents / sub agents \\
\hline $1 / 074$ & $15 / 33$ & $7 / 128$ & $8 / 202$ & Team and teamwork \\
\hline $0 / 036$ & $2 / 051$ & $1 / 007$ & $1 / 044$ & Goals and mission of fever \\
\hline $0 /-014$ & 2/019 & $1 / 016$ & $1 / 003$ & Team of the knowledge -based \\
\hline $0 / 025$ & $1 / 886$ & $0 / 93 / 0$ & $0 / 955$ & Reward based on people's participation, \\
\hline $0 /-047$ & $1 / 857$ & $0 / 952$ & $0 / 905$ & System measures of performance to assess the work team \\
\hline $1 /-672$ & $15 / 63$ & $8 / 653$ & $6 / 981$ & Communication and awareness \\
\hline $0 /-012$ & $1 / 995$ & $1 / 004$ & $0 / 991$ & Exchange goals strategically, eyes bumps \\
\hline $0 /-05$ & $1 / 941$ & 0/971 & 0/97 & Senior management support \\
\hline $0 /-02$ & $1 / 928$ & $0 / 974$ & $0 / 954$ & Channels of communication of and exchange of information. \\
\hline $0 / 033$ & $1 / 787$ & $0 / 877$ & $0 / 91$ & Check customer information \\
\hline $0 /-58$ & $16 / 95$ & $8 / 763$ & $8 / 183$ & Empowering staff \\
\hline $0 /-089$ & $1 / 252$ & $0 / 671$ & $0 / 582$ & Delegate authority to employees \\
\hline $0 / 033$ & $1 / 471$ & $0 / 719$ & $0 / 752$ & Enabling staff \\
\hline $0 / 056$ & $1 / 358$ & $0 / 651$ & $0 / 707$ & Commitment of staff \\
\hline $0 / 936$ & $14 / 86$ & $6 / 964$ & $7 / 9$ & Process map \\
\hline $0 /-054$ & $1 / 36$ & $0 / 707$ & $0 / 653$ & Input to and output in the key of each process \\
\hline $0 / 053$ & $1 / 44$ & $0 / 694$ & $0 / 746$ & Identify suppliers and customers key for each process \\
\hline $0 / 043$ & $1 / 407$ & $0 / 703$ & $0 / 704$ & Process map design and flow chart \\
\hline $0 / 903$ & $16 / 57$ & $7 / 833$ & $8 / 736$ & Education \\
\hline $0 /-072$ & $1 / 917$ & 0/994 & $0 / 923$ & Learning skills for identifying and solving problems \\
\hline $0 / 126$ & $2 / 05$ & $0 / 962$ & $1 / 088$ & Control and improve the quality and expertise to the head of the team \\
\hline $0 /-016$ & $1 / 904$ & $0 / 96$ & $0 / 944$ & Teaching skills working team of staff \\
\hline $0 /-039$ & $1 / 995$ & $1 / 017$ & $0 / 978$ & Learning the skill of reaction \\
\hline $0 /-727$ & $15 / 13$ & $7 / 928$ & $7 / 202$ & Change Management \\
\hline $0 / 019$ & $1 / 445$ & $0 / 713$ & $0 / 732$ & Change management skills in the organization \\
\hline $0 /-039$ & $1 / 435$ & $0 / 737$ & $0 / 698$ & Preparedness in the face of change \\
\hline $0 / 021$ & $1 / 456$ & $0 / 717$ & $0 / 738$ & Skills and extensive in management project \\
\hline $0 /-650$ & $16 / 02$ & $7 / 976$ & $8 / 041$ & Technology Information \\
\hline $0 /-08$ & $1 / 9$ & $0 / 99$ & $0 / 91$ & The ability of IT \\
\hline $0 / 035$ & $2 / 038$ & $1 / 002$ & $1 / 037$ & The construction of IT \\
\hline $0 / 026$ & $2 / 062$ & $1 / 018$ & $1 / 044$ & Database \\
\hline $0 / 019$ & $2 / 076$ & $1 / 029$ & $1 / 047$ & Network of information \\
\hline
\end{tabular}

Farzaneh Zafary Asheghdoost

Ranking Factors Affecting Organizational Readiness to Implement Enterprise Resource Planning Systems Using

Fuzzy-Dimensional Network Analysis
ADCAIJ: Advances in Distributed Computing and Artificial Intelligence Journal Regular Issue, Vol. 8 N. 3 (2019), 35-50 eISSN: 2255-2863 - http://adcaij.usal.es Ediciones Universidad de Salamanca - CC BY NC DC 
In this research, balanced super matrix was formed to gain weight of agents. This super matrix was obtained by normalizing the general relations matrix (T), as shown in Table (7). Also, to obtain the weight of the factors, a balanced super matrix was enabled. Converged at the power of 5 super matrix and fuzzy bound super matrix was obtained. By obtaining the limiting super matrix, weights of factors and sub-factors were determined, as shown in Table (8). The weight of these agents is the same as the super matrix numbers. The weight of the main factors was also calculated from the sum of the final weight of the sub-factors.

Table 7: Fuzzy Tuning Super matrix

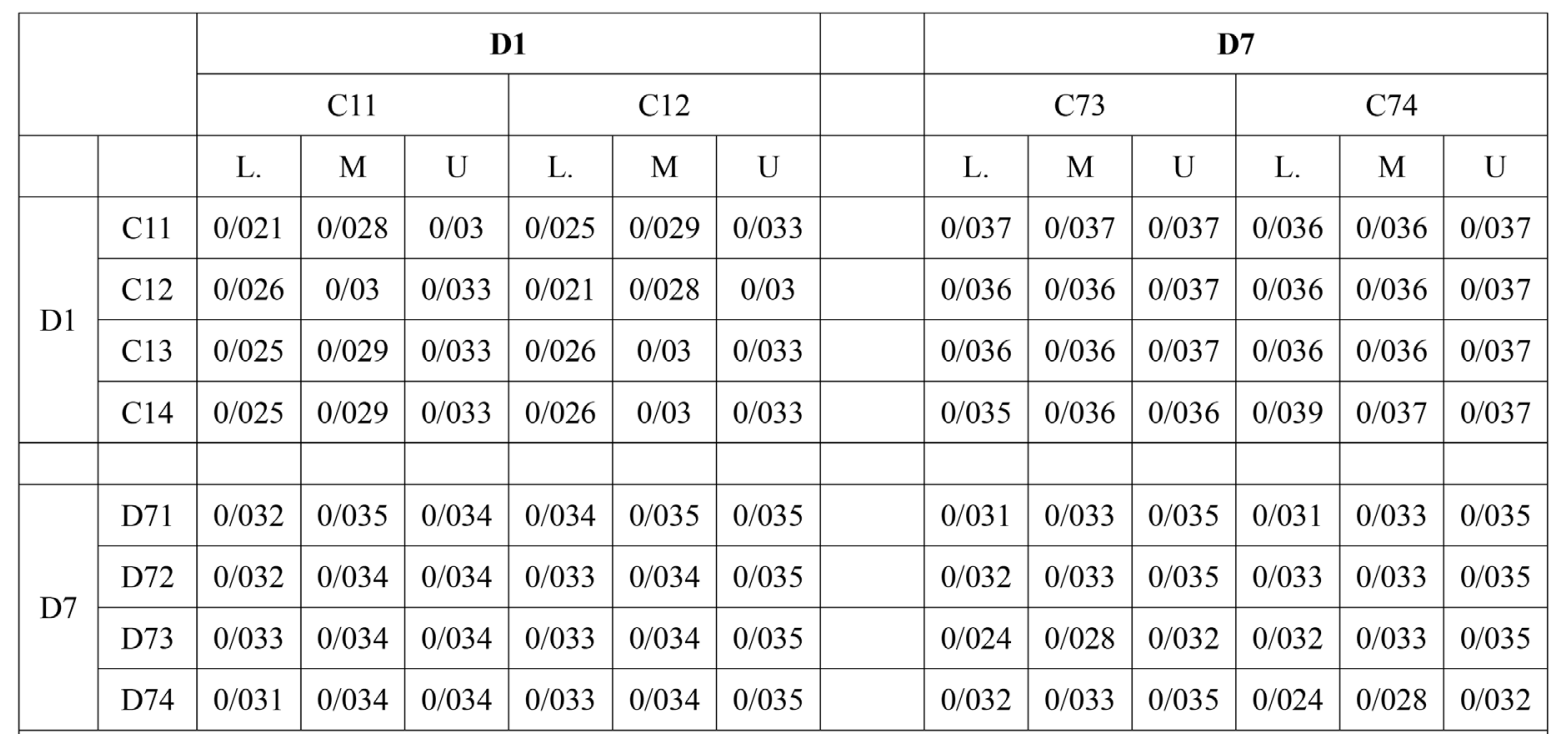

Note: With respect to a matrix of $25 * 25$ and the low-page matrix, all the tables can be displayed compact.

Farzaneh Zafary Asheghdoost

Ranking Factors Affecting Organizational Readiness to Implement Enterprise Resource Planning Systems Using Fuzzy-Dimensional Network Analysis
ADCAIJ: Advances in Distributed Computing and Artificial Intelligence Journal Regular Issue, Vol. 8 N. 3 (2019), 35-50 elSSN: 2255-2863 - http://adcaij.usal.es Ediciones Universidad de Salamanca - CC BY NC DC 


\begin{tabular}{|c|c|c|c|c|c|c|c|c|c|c|c|c|c|c|c|c|c|c|c|c|c|c|c|c|c|c|}
\hline \multirow{3}{*}{ 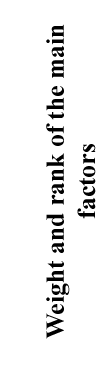 } & & \multicolumn{5}{|c|}{ 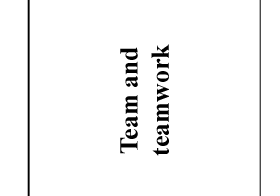 } & \multicolumn{3}{|c|}{ 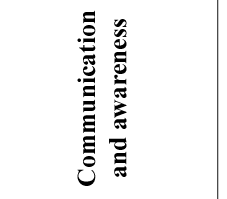 } & \multicolumn{3}{|c|}{ 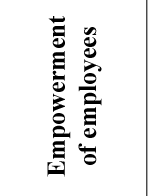 } & \multicolumn{3}{|c|}{ 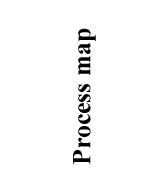 } & \multicolumn{4}{|c|}{ 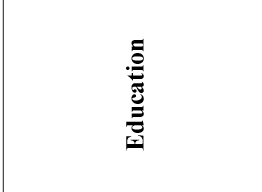 } & \multicolumn{3}{|c|}{ 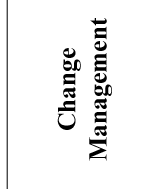 } & \multicolumn{4}{|c|}{ 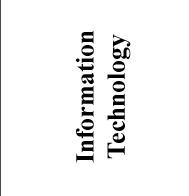 } \\
\hline & & \multicolumn{4}{|c|}{$\begin{array}{l}\overrightarrow{\mathrm{n}} \\
\frac{\mathrm{d}}{0}\end{array}$} & \multicolumn{4}{|c|}{$\frac{a}{0}$} & \multicolumn{3}{|c|}{$\frac{\stackrel{\infty}{b}}{\stackrel{0}{0}}$} & \multicolumn{3}{|c|}{$\stackrel{m}{\Im}$} & \multicolumn{4}{|c|}{$\stackrel{0}{\frac{J}{J}}$} & \multicolumn{3}{|c|}{$\frac{\text { o }}{\stackrel{+}{9}}$} & \multicolumn{4}{|c|}{$\frac{\text { fे }}{\partial}$} \\
\hline & & \multicolumn{4}{|c|}{0} & \multicolumn{4}{|c|}{$N$} & \multicolumn{3}{|c|}{-} & \multicolumn{3}{|c|}{ r } & \multicolumn{4}{|c|}{+} & \multicolumn{3}{|c|}{ in } & \multicolumn{4}{|c|}{ m } \\
\hline 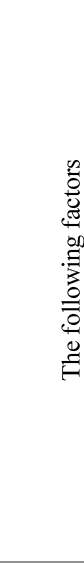 & & 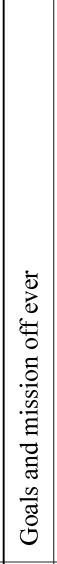 & 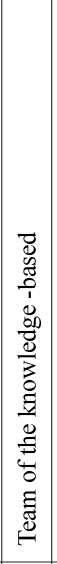 & 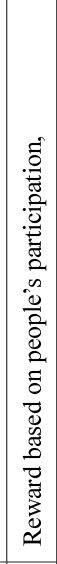 & 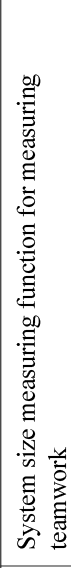 & 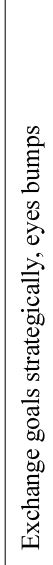 & 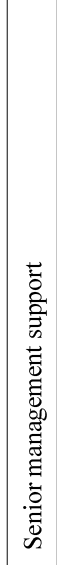 & 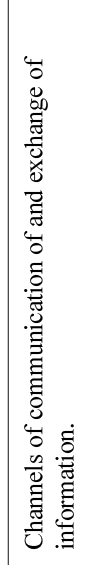 & 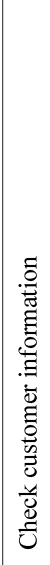 & 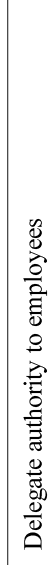 & 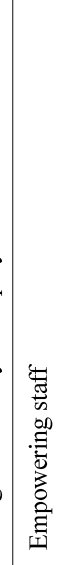 & 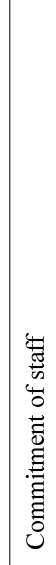 & 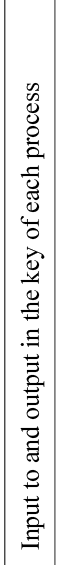 & 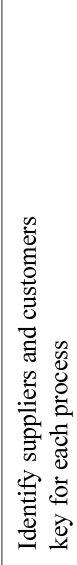 & 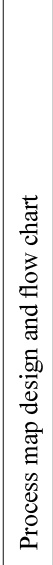 & 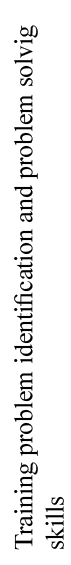 & 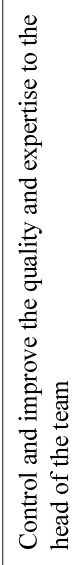 & 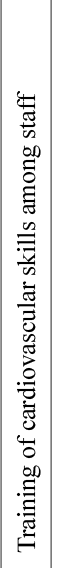 & 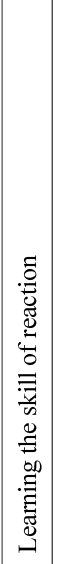 & 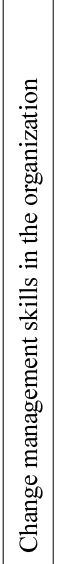 & 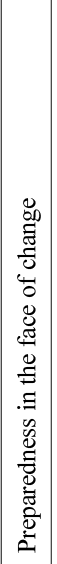 & 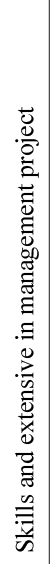 & 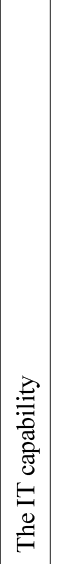 & 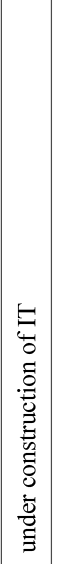 & 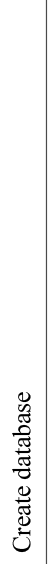 & 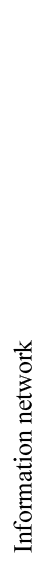 \\
\hline \multirow{2}{*}{\multicolumn{2}{|c|}{ 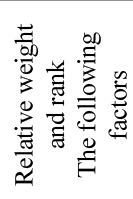 }} & 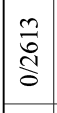 & 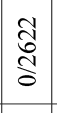 & $\begin{array}{l}\vec{\delta} \\
\widetilde{I} \\
\delta\end{array}$ & 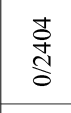 & $\begin{array}{l}\text { 导 } \\
\text { ऽ̦ }\end{array}$ & $\begin{array}{l}0 \\
\text { In } \\
\text { In }\end{array}$ & 蒿 & \begin{tabular}{|l}
$\infty$ \\
त̃ \\
ปn
\end{tabular} & స̂. & 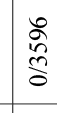 & $\frac{m}{m}$ & $\begin{array}{l}\tilde{N} \\
\tilde{J} \\
\delta\end{array}$ & 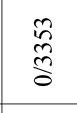 & હે & 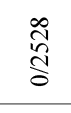 & 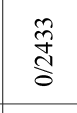 & 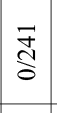 & $\begin{array}{l}\text { त్ } \\
\text { ড̇ } \\
\end{array}$ & $\begin{array}{l}\tilde{O} \\
\tilde{N} \\
\tilde{\delta}\end{array}$ & \begin{tabular}{|l|}
$\frac{n}{f}$ \\
$\frac{n}{\delta}$ \\
\end{tabular} & $\begin{array}{l}\vec{D} \\
\tilde{ల} \\
\delta\end{array}$ & 辛 & 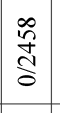 & 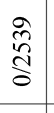 & $\begin{array}{l}\text { 点 } \\
\text { ป } \\
\end{array}$ \\
\hline & & $\sim$ & - & 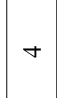 & $m$ & - & N & m & t & 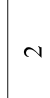 & - & $m$ & $\mathrm{~N}$ & - & $m$ & $\sim$ & m & $\nabla$ & - & $m$ & - & N & $\nabla$ & $m$ & $N$ & - \\
\hline \multirow{2}{*}{\multicolumn{2}{|c|}{ 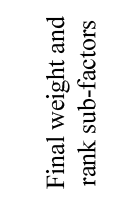 }} & $\begin{array}{l}\hat{1} \\
\hat{O} \\
\delta\end{array}$ & $\begin{array}{l}\infty \\
\stackrel{\infty}{1} \\
\stackrel{0}{0}\end{array}$ & 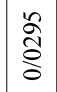 & 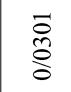 & 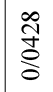 & 妾 & $\overrightarrow{\bar{g}}$ & $\begin{array}{l}\text { ठ̊ } \\
\stackrel{\delta}{\delta} \\
\end{array}$ & 命 & $\begin{array}{l}\text { ồ } \\
\delta\end{array}$ & $\begin{array}{l}0 \\
\frac{0}{\delta} \\
\delta\end{array}$ & $\begin{array}{l}\text { t⿱ } \\
\text { d } \\
\text { O }\end{array}$ & $\begin{array}{l}\text { ò } \\
\text { ờ }\end{array}$ & 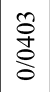 & 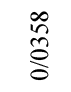 & 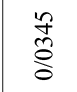 & $\begin{array}{l}F \\
\stackrel{\tilde{O}}{\delta}\end{array}$ & $\begin{array}{c}\stackrel{N}{\hat{O}} \\
\stackrel{\delta}{O}\end{array}$ & $\begin{array}{l}\bar{b} \\
\stackrel{0}{0} \\
0\end{array}$ & $\stackrel{\infty}{\stackrel{0}{0}}$ & $\begin{array}{l}\text { ț } \\
\text { d̦ } \\
\text { o }\end{array}$ & $\begin{array}{l}\hat{\aleph} \\
\hat{\delta} \\
\delta\end{array}$ & $\begin{array}{l}0 \\
\stackrel{0}{0} \\
\hat{\delta}\end{array}$ & $\begin{array}{l}\infty \\
\stackrel{\infty}{0} \\
0 \\
0\end{array}$ & 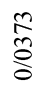 \\
\hline & & $\ddot{\imath}$ & $\pi$ & $\therefore$ & $\stackrel{\sim}{\sim}$ & $r$ & $\infty$ & $a$ & $\stackrel{0}{0}$ & $\alpha$ & - & m & $=$ & 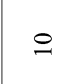 & $\simeq$ & $=$ & ì & $\vec{N}$ & $\Xi$ & 0 & $\sigma$ & in & 2 & $\stackrel{\infty}{\sim}$ & 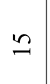 & 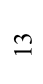 \\
\hline \multirow{3}{*}{ 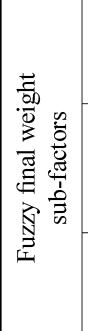 } & $D$ & 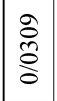 & $\begin{array}{l}\text { oे } \\
\text { : } \\
\text { Oे }\end{array}$ & \begin{tabular}{|l} 
to \\
S̆
\end{tabular} & 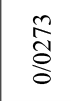 & $\begin{array}{l}\text { 等 } \\
\text { }\end{array}$ & 旁 & $\begin{array}{l}\frac{0}{0} \\
\frac{+}{8}\end{array}$ & $\begin{array}{l}\infty \\
\stackrel{\circ}{0} \\
\stackrel{8}{0}\end{array}$ & 令 & $\begin{array}{l}\infty \\
0 \\
0 \\
0\end{array}$ & 羙 & 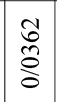 & $\begin{array}{l}\text { Oे } \\
\text { ổ } \\
\text { Oे }\end{array}$ & $\begin{array}{l}8 \\
\stackrel{0}{0} \\
\stackrel{0}{0}\end{array}$ & $\begin{array}{l}\stackrel{\infty}{\infty} \\
\stackrel{\rho}{0}\end{array}$ & 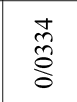 & 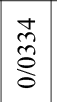 & \begin{tabular}{|c|}
$\infty$ \\
$\infty$ \\
$\tilde{O}$ \\
0
\end{tabular} & 站 & \begin{tabular}{|l|} 
\\
\\
0 \\
0 \\
0
\end{tabular} & 导 & $\frac{n}{\delta}$ & \begin{tabular}{|l|}
$\tilde{\tilde{n}}$ \\
$\hat{\delta}$ \\
\end{tabular} & $\begin{array}{l}\stackrel{n}{o} \\
\hat{o} \\
0\end{array}$ & $\begin{array}{l}\text { 足 } \\
\stackrel{0}{0} \\
\stackrel{0}{0}\end{array}$ \\
\hline & $\Sigma$ & 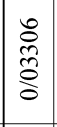 & $\begin{array}{l}\overline{\tilde{\delta}} \\
\stackrel{\tilde{\delta}}{0}\end{array}$ & 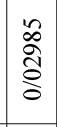 & $\begin{array}{l}\overrightarrow{\hat{n}} \\
\stackrel{0}{0} \\
\delta\end{array}$ & 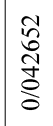 & 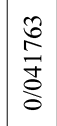 & $\begin{array}{l}\frac{\partial}{0} \\
\frac{\vec{\sigma}}{\partial}\end{array}$ & 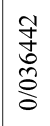 & $\begin{array}{l}\overline{\bar{\infty}} \\
\hat{\delta} \\
\hat{\delta}\end{array}$ & 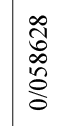 & 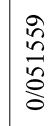 & 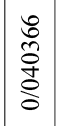 & 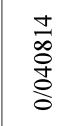 & 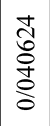 & 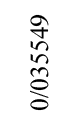 & 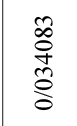 & $\begin{array}{l} \\
\overrightarrow{⿱ 亠 े} \\
\stackrel{\partial}{\partial}\end{array}$ & 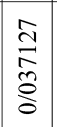 & 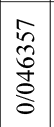 & 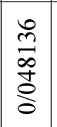 & 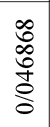 & \begin{tabular}{|l|}
$\infty$ \\
$\infty$ \\
$\infty$ \\
0 \\
0 \\
0 \\
0
\end{tabular} & \begin{tabular}{|l|}
$\hat{N}$ \\
$\tilde{n}$ \\
$\hat{\delta}$ \\
$\partial$
\end{tabular} & 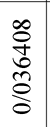 & 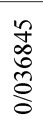 \\
\hline & - & 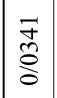 & 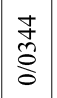 & 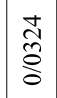 & 芯 & 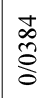 & 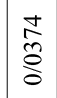 & $\stackrel{\text { ô }}{\hat{o}}$ & $\begin{array}{l}\text { 令 } \\
\stackrel{8}{0}\end{array}$ & 旁 & 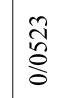 & $\overrightarrow{\bar{o}}$ & 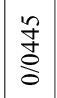 & $\begin{array}{l}\frac{\text { of }}{\partial} \\
\text { Oे }\end{array}$ & $\hat{\bar{q}}$ & §̊ & ळ̂̊े & $\begin{array}{l}\stackrel{g}{\mathrm{O}} \\
\text { o }\end{array}$ & $\begin{array}{l}\stackrel{\delta}{0} \\
\check{O} \\
0\end{array}$ & 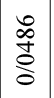 & 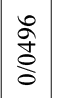 & 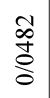 & $\begin{array}{l}\tilde{c} \\
\hat{o} \\
0\end{array}$ & $\begin{array}{l}\infty \\
0 \\
0 \\
0\end{array}$ & $\begin{array}{l}0 \\
\stackrel{0}{0} \\
0 \\
0\end{array}$ & 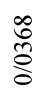 \\
\hline
\end{tabular}

Farzaneh Zafary Asheghdoost

Ranking Factors Affecting Organizational Readiness to Implement Enterprise Resource Planning Systems Using Fuzzy-Dimensional Network Analysis
ADCAIJ: Advances in Distributed Computing and Artificial Intelligence Journal

Regular Issue, Vol. 8 N. 3 (2019), 35-50 eISSN: 2255-2863 - http://adcaij.usal.es Ediciones Universidad de Salamanca - CC BY NC DC 
As Table 8 shows, the factor of "Empowering the staff" is the most important factor, and according to experts, this factor contributes to the success of the organization in the implementation of business process management systems. Therefore, through empowerment, employees can better manage their work and contribute to the successful implementation of business process management systems through their actions and participation. Employee Empowerment (0.593) has the highest priority among other sub factors, and is most important in the implementation of business process management systems. Staff must be able to take appropriate action. This ability enables them to decide and take appropriate action for unforeseen events. The following are the priorities given to employees: delegation of staff, commitment to staff, readiness to change, extensive project management skills, and change management skills in the organization, respectively. This result suggests that managers need to prioritize more success factors in order to succeed in implementing more business process management systems. Empowering employees motivates them to become more involved in the process.

\section{Conclusion}

The purpose of this study is to pay attention to the pre-implementation phase of ERP. Also, by combining strategic management and multi-criteria decision making, the researcher intend to present "Key Factors of Successful Implementation of ERP System" model and prioritize factors and strategies while categorizing organizational strengths, weaknesses, opportunities, and threats. The findings of this study were obtained by distributing a questionnaire among 10 experts in the field under study. The main purpose of data analysis was to examine the phenomena and relationships between variables of the research subject. After analyzing the data collected on the research topic, the sources of the proposed model of the present study, which prioritize the main criteria using fuzzy-dimensional network analysis technique, were investigated to answer the questions posed at the beginning of this research. In response to the first and second research questions, 25 sub-factors screened by Delphi technique were categorized as strengths, weaknesses, opportunities and threats. According to the results of Dematel and Table (6) the "team and teamwork" factor with the highest DR is the most influential and important factor among the main factors affecting the implementation of ERP systems in Birjand university. It can play a key role in the implementation of ERP systems and should therefore be a top management priority. Therefore, the organization should improve the team and teamwork (C1) factor along with other factors to prepare the organization for implementing of Enterprise resource planning system. The "communication and awareness" factor has the least (D-R) influential factor in ERP implementation. Special attention must be paid to team and teamwork to improve communication and awareness. In other words, "communication and awareness" is the most impressionable factor that can be improved by the most influential "team and teamwork" factor. In general, in order to implement enterprise resource planning system, respectively, team and teamwork factors, process role, training, information technology, staff empowerment, change management, communication and awareness for organization readiness should be improved. Therefore, managers are suggested to base their results on: (1) customer information review, (2) senior management support, (3) strategic goals and perspectives exchange, and (4) different communication and information exchange channels, improving agent performance of "Communication and Consciousness". Managers are also suggested to improve the effectiveness of sub-factors, including clarifying group goals and missions, rewarding participatory, knowledge-based groups, and improving performance measurement systems for measuring teamwork based on DEMTEL, teamwork, and workgroup. The results of the network analysis process method for weighting and prioritizing the factors and sub-factors showed that among the main factors, employees' empowerment factors, communication and awareness, information technology, education, change management, group and team work and process role are first to seventh priority, respectively. This result suggests that managers need to pay more attention to employee empowerment in order to be successful in implementing ERP systems. Managers are suggested to empower employees by committing employees to the organization, employee empowerment, and delegation of authority. Because these sub-factors were based on DEMTEL results respectively. Among the sub-factors, 'staff empowerment' is most important and is a top priority in the implementation of ERP systems. Therefore, managers must empower employees to take appropriate action. This empowerment can be motivated by education and material rewards through education. Empowerment is the healthiest way to share power with other

Farzaneh Zafary Asheghdoost

Ranking Factors Affecting Organizational Readiness to

Implement Enterprise Resource Planning Systems Using

Fuzzy-Dimensional Network Analysis
ADCAIJ: Advances in Distributed Computing and Artificial Intelligence Journal Regular Issue, Vol. 8 N. 3 (2019), 35-50 elSSN: 2255-2863 - http://adcaij.usal.es Ediciones Universidad de Salamanca - CC BY NC DC 
employees, and the organization should be able to create a system of identification and reward based on the participation of individuals, in order to have a positive effect on employee empowerment. Of course, the organization should not ignore the potential risks when empowering them. Also, the organization should create a model for change preparedness. Based on the results of the network analysis process, "delegating authority" became the second priority. This result suggests that managers should create an authorization system along with identifying responsibilities within the organization. Given that employee commitment is the third priority in this survey, managers can reinforce their commitment to the organization by using leadership styles and creating organizational identity within employees.

\section{Research suggestions}

This study attempted to analyze all dimensions and indicators of successful implementation of ERP system model, but since there are very few field studies in academic communities, future researchers can improve their research by increasing their range of studies and through the identification and modification of items and agents. The use of fuzzy logic in pairwise comparisons to overcome ambiguities associated with linguistic expression is suggested in similar studies. Another similar approach is the use of gray relationship analysis, which is less complex. It is recommended that both gray matter analysis techniques be used to determine criteria weighting and priority setting. Since the findings of this study cannot be generalized to other statistical population, it is suggested that similar research be conducted at other universities in the country to increase the validity of the research. It can be said that the findings of this study provide an opportunity for other researchers through cost optimization approach as well as a time to improve readiness for successful ERP implementation.

\section{References}

Abdinnour-Helm, S., Lengnick-Hall, M.L. and Lengnick-Hall., C.A., 2003. 'Pre-implementation attitudes and organizational readiness for implementing an Enterprise Resource Planning system', European Journal of Operational Research, 146, 258-273

Abdollah Zadeh, SA. and Good man, M., 2009. "Design and Implementation of Model Based on Organizational Resource Planning System (ERP) in Urmia University of Technology".

Abolhasani, AS. and Mal Husseini, AS., 2010. "Risk Analysis of ERP Project Implementation, Using Fuzzy Logic (Case Study: Active in Automotive Industry)". Journal of Industrial Management. Faculty of Humanities, Islamic Azad University.

Afaneh, S., AlHadid, I and AlMalahmeh, H., 2015. 'Relationship Between Organizational Factors, Technological Factors and Enterprise Resource Planning System Implementation'. International Journal of Managing Information Technology (IJMIT), 7

Ahmadi, S., Yeh, C.H., Papageorgiou, E.I. and Martin, R., 2015a. 'An FCM-FAHP approach for managing readiness-relevant activities for ERP implementation'. Computers \& Industrial Engineering, 88, 501- 51

Ahmadi, S., Yeh, C-H., Martin, R. and Papageorgiou, E. I., 2015b. 'Optimizing ERP readiness improvements under budgetary constraints'. International Journal Of Production Economics, 161, 105-115

Ahmadi, S., Papageorgiou, E.I., Yeh, C.H. and Martin, R., 2015c. 'Managing readiness-relevant activities for the organizational dimension of ERP implementation'. Computers in Industry, 68, 89-10

Al-Muharfi, A.R.A., 2014. 'Accounting Information System Lessons from Implementation Enterprise Resource Planning in Saudi Case Study'. Academic Journals Inc, 7, 326-34

Asadi, F., Taban, M and Safari Kahr, M.A., 2013. "Analyzing the Strategic Status of Nonprofit Universities and Higher Education Institutions in Iran: Applying a Comprehensive Strategic Analysis Approach”, Journal of Business Management, Volume 5, Number 3, pp. 19-3.

Bandara, W., Alibabaei, A., \& Aghdasi, M. (2009 september 25-27). Means of achieving business process management success factors. In P. Ein-Dor, A. Poulymenakou, \& M. Amami (Eds.), Proceedings of the 4th Mediterranean conference on information systems. Athens: Athens University of Economics and Business.

Farzaneh Zafary Asheghdoost

Ranking Factors Affecting Organizational Readiness to Implement Enterprise Resource Planning Systems Using

Fuzzy-Dimensional Network Analysis
ADCAIJ: Advances in Distributed Computing and Artificial Intelligence Journal Regular Issue, Vol. 8 N. 3 (2019), 35-50 eISSN: 2255-2863 - http://adcaij.usal.es Ediciones Universidad de Salamanca - CC BY NC DC 
Baidoun, S. (2004). The implementation of TQM philosophy in Palestinian organization: a proposed non-prescriptive generic framework. The TQM Magazine, 16(3), 174-185.

Bighrissen, B., Ettamiri, E.M., Cherkaoui C., 2012. 'Towards the Success of ERP Systems: Case Study in Two Moroccan Companies'. Journal of Enterprise Resource Planning Studies-17. doi: 10.5171/2012.731113

Castro Silva, S.L.F. and Oliveira, S.B., 2015. 'Planning and scope definition to implement ERP: The case study of Federal Rural University of Rio de Janeiro (UFRRJ)'. Procedia Computer Science, 64, 196-203

Chang, B., Chang, C.W. and W.U, C.H., 2011. 'Fuzzy DEMATEL method for developing supplier selection criteria, Expert Systems with Applications'. International Journal of Expert Systems with Applications, 38, 1850-1858.

Dempsey, B.S., Vance, R and Sheehan, L., 2013. 'Justification of An Upgrade of An Enterprise Resource Planning (ERP) System - The Accountant's Role'. Global Journal of Human Social Science, 13.

Doddaiah, S.V., Mallur, S.B. and Yadwad, A.M., 2014. 'Migrating from Legacy Enterprise Resource Planning (ERP) System to a New ERP System: A Case Study'. International Journal of Research in Engineering and Technology, 3, 2319-1163.

Habibi, A., Izadyar, AH and pride, A., 2014. "Fuzzy Multi Criteria Decision Making". Gilles Inscription, Tehran.

Haji Sadeghi, B., Niroomand, P, Ranjbar, M., 2011. A framework for measuring BPM implementation readiness in Tehran Regional Electricity Company. Improvement Management, No. 63, pp. 183-201.

Helm, R., 2005. 'The future according to Frederik Lodewijk Polak: finding the roots of contemporary futures studies'. Futures, 37(6), 505-519

Hidayanto, A., Hasibuan, M., Handayani, P and Sucahyo, Y., 2013. Framework for Measuring ERP Implementation Readiness in Small and Medium Enterprise (SME): A Case Study in Software Developer Company. Journal Of Computers, 8(7). doi: 10.4304/jcp.8.7.1777-1782

Hoch, J.E, Dulebohn, J.H., 2013. 'Shared leadership in enterprise resource planning and human resource management system implementation'. Human Resource Management Review, 23, 114-125

Hnafizadeh, P, Zare Ravasan, A., 2011. 'A McKinsey 7S Model -Based Framework for ERP Readiness Assessment'. International Journal of Enterprise Information Systems, 7, 23- 63

Juran, J. M., Blanton Godfery, A. (2000). Juran \& apos; s Quality Handbook. 5th ed

Kalhori, A., Haji Haidari, N. (2012). Identify and evaluate the factors that influence the readiness to implement business processes management. Management and Development Process, Volume 25, Number 2, pp. 52-69.

Kocaoglu, B and Acar, A.Z., 2015. 'Developing an ERP Triggered Business Process Improvement Cycle from a Case Company', Procedia - Social and Behavioral Sciences, 181, 107-114

Landeta J., 2006. 'Current validity of the Delphi method in social sciences'. Technological Forecasting and Social Change, 73, 467-82

Master, A., 2010. "Application of Network Analysis Process (ANP) in Urban Planning and Logics". Journal of Fine Arts, Architecture and Urban Planning, Volume 2, Number 41.

McSweeney, B. (2009) 'Incoherent culture', European J. Cross-Cultural Competence and Management, Vol. 1, No. 1, pp.22-27.

Moradi, C., Amiri, M and Moradi, M., 2013. "Investigation of the Main Factors of ERP System Deployment by Fuzzy TOPSIS Method in Subsidiaries of Ministry of Energy". 28th International Electricity Conference, November 15-15, Tehran.

Mr. and Fazli, ah., 2012. "Using the Combined Approach of DEMATEL and ANP to Choose the Appropriate Maintenance Strategy. Case Study: The Work Automotive Industry (Perspective on Industrial Management, No. 6, pp. 89-107).

Mukhtari, d. and Moez, Q., 2015. "Evaluation of Analytical Hierarchy Process (AHP) (and Network Analysis Process) ANP (Investigation of Some Effective Hydro Geomorphological Factors in Water Supply and Habitat Replacement (Case Study: Miandoab Plain)". Journal of Natural Geography, Volume 8, Number 30, pp. 31-52.

Musikhani, M., Mirshaji, Q.A. Hassanzadeh, R and righteous, D., 2014. "Providing a Model for Measuring the Requirements of ERP Project Implementation: A Case Study of Qazvin Azad University". Quarterly Journal of Management Development, No. 19, pp. 1-9.

Farzaneh Zafary Asheghdoost

Ranking Factors Affecting Organizational Readiness to

Implement Enterprise Resource Planning Systems Using

Fuzzy-Dimensional Network Analysis
ADCAIJ: Advances in Distributed Computing and Artificial Intelligence Journal Regular Issue, Vol. 8 N. 3 (2019), 35-50 elSSN: 2255-2863 - http://adcaij.usal.es Ediciones Universidad de Salamanca - CC BY NC DC 
Nazemi, Shamsuddin, Fathi, A.S and Watch, A., 2010. "Applying the Combined Model of Fuzzy Hierarchical Analysis and Swat Analysis in Strategic Planning of Higher Education (Case Study: Ferdowsi University of Mashhad)". Journal of Science and Technology, Issue 2.

Nazemi, E., Tarokh, M.J. and Djavanshir, G. R., 2012. 'ERP: a literature survey'. International Journal of Advanced Manufacturing Technology, 61, 999-1018.

Ravesteyn, P., (2010). Surveying the critical success factors of BPM-systems implementation. Business Process Management Journal, Vol. 16, No (3) q, Emerald Group Publishing Limited, pp. 492-507.

Rajnoha, R., Kádárová, J., Sujová, A and Kádár, G., 2014. 'Business information systems: research study and methodological proposals for ERP implementation process improvement'. Procedia - Social and Behavioral Sciences, 109, 165-170.

Razmi, J., Sangari, M. S and Ghodsi, R., 2009. 'Developing a practical framework for ERP readiness assessment using fuzzy analytic network process'. Advances in Engineering Software, 40, 1168-1178.

Rezaei, K., Tadayin, S., Professor Bakhtiar and Aghdasi, M. (1388). Key success factors in implementing process management and providing a framework for evaluating organizational readiness. Industrial Management, Volume 1, pp. 37-52.

Sadeghi, A., Jafari, H., KHodayari, R., Pakdaman, M., Mohammadi, R. \& Ahadi, N. (2011). A case study: the association between organizational culture with management knowledge in Hasheminezhad hospital - Tehran, Journal of Hospital, 3(2):1-7.

Sevkli, M., Oztekin, A., Uysal, O., Torlak, G., Turkyilmaz, A, Delen, D., 2012. 'Development of a fuzzy ANP based SWOT analysis for the airline industry in Turkey'. Expert Systems with Applications, 39, 14-24.

Shafaei, R and Dabiri, N., 2008. 'An EFQM Based Model to Assess an Enterprise Readiness for ERP Implementation'. Journal of Industrial and Systems Engineering, 2, 51-74.

Shokrali, M., 2010. "Evaluation of Performance Factors of ERP Systems after Implementation in Iranian Large Companies (Case Study: Isfahan Steel Company)". MSc in Information Technology Engineering, Faculty of Engineering, Tarbiat Modares University.

Niroomand, P., Ranjbar, M., Arabi, M., Haji Sadeghi, B., 2014. Providing a framework for designing a business model. Information Technology Management, Volume 5, Number 4, pp. 284-267.

Niroomand, P,Ranjbar, M., 2012. Identifying and classifying mobile business models based on the Hybrid approach. Information Technology Management, Volume 4, Number 10, pp. 179-20.

Telleria, P. K., Little, D., MacBryde, J. (2002), "Managing processes through teamwork", Business Process Management Journal, Vol. 8 No. 4, pp. 338-350. https://doi.org/10.1108/14637150210434991.

Yarmohammadian, M.H., Ebrahimipour, H, Dosti, F., 2011. Understanding the Business Process Management Approach in Health Care Organizations. Health Information Management, Volume 9, Number 7, pp. 1123-1131.

Farzaneh Zafary Asheghdoost

Ranking Factors Affecting Organizational Readiness to Implement Enterprise Resource Planning Systems Using

Fuzzy-Dimensional Network Analysis
ADCAIJ: Advances in Distributed Computing and Artificial Intelligence Journal Regular Issue, Vol. 8 N. 3 (2019), 35-50 elSSN: 2255-2863 - http://adcaij.usal.es Ediciones Universidad de Salamanca - CC BY NC DC 